\title{
Retraction Note: Effect of sagittal femoral component alignment on biomechanics after mobile-bearing total knee arthroplasty
}

Yong-Gon Koh ${ }^{1 \dagger}$, Jin-Ah Lee ${ }^{2 \dagger}$, Hwa-Yong Lee ${ }^{2}$, Dong-Suk Suh ${ }^{1}$, Hyo-Jeong Kim ${ }^{3}$ and Kyoung-Tak Kang ${ }^{2 *}$

Retraction Note: J Orthop Surg Res 14, 400 (2019)

https://doi.org/10.1186/s13018-019-1458-5

The Editor-in-Chief has retracted this article because it contains material that substantially overlaps with the following works (among others) [1-4].

Jin-Ah Lee does not agree to this retraction. YongGon Koh, Hwa-Yong Lee, Dong-Suk Suh, Hyo-Jeong Kim \& Kyoung-Tak Kang have not responded to any correspondence from the publisher about this retraction.

4. Kang KT, Koh YG, Son J, Kwon OR, Lee JS, Kwon SK. Influence of increased posterior tibial slope in total knee arthroplasty on knee joint biomechanics: a computational simulation study. J Arthroplast. 2018;33(2):572-9. https:// doi.org/10.1016/j.arth.2017.09.025.

\section{Author details}

${ }^{1}$ Joint Reconstruction Center, Department of Orthopaedic Surgery, Yonsei Sarang Hospital, 10 Hyoryeong-ro, Seocho-gu, Seoul 06698, Republic of Korea. ${ }^{2}$ Department of Mechanical Engineering, Yonsei University, 50

Yonsei-ro, Seodaemun-gu, Seoul 03722, Republic of Korea. ${ }^{3}$ Department of Sport and Healthy Aging, Korea National Sport University, 1239

Yangjae-dearo, Songpa-gu, Seoul 05541, Republic of Korea.

Published online: 10 March 2021

\section{References}

1. Haas BD, Komistek RD, Stiehl JB, Anderson DT, Northcut EJ. Kinematic comparison of posterior cruciate sacrifice versus substitution in a mobile bearing total knee arthroplasty. J Arthroplast. 2002;17(6):685-92. https://doi. org/10.1054/arth.2002.33550.

2. Kang KT, Kwon SK, Son J, Kwon OR, Lee JS, Koh YG. Effects of posterior condylar offset and posterior tibial slope on mobile-bearing total knee arthroplasty using computational simulation. Knee. 2018;25(5):903-14. https://doi.org/10.1016/j.knee.2018.06.011.

3. Koh YG, Hong HT, Lee HY, Kim HJ, Kang KT. Influence of variation in sagittal placement of the femoral component after cruciate-retaining Total-knee Arthroplasty. J Knee Surg. 2019. https://doi.org/10.1055/s-0039-1696958.

The original article can be found online at https://doi.org/10.1186/s13018019-1458-5.

*Correspondence: tagi1024@gmail.com

${ }^{\dagger}$ Yong-Gon Koh and Jin-Ah Lee contributed equally to this work.

${ }^{2}$ Department of Mechanical Engineering, Yonsei University, 50 Yonsei-ro, Seodaemun-gu, Seoul 03722, Republic of Korea

Full list of author information is available at the end of the article

C C The Author(s). 2021 Open Access This article is licensed under a Creative Commons Attribution 4.0 International License, which permits use, sharing, adaptation, distribution and reproduction in any medium or format, as long as you give appropriate credit to the original author(s) and the source, provide a link to the Creative Commons licence, and indicate if changes were made. The images or other third party material in this article are included in the article's Creative Commons licence, unless indicated otherwise in a credit line to the material. If material is not included in the article's Creative Commons licence and your intended use is not permitted by statutory regulation or exceeds the permitted use, you will need to obtain permission directly from the copyright holder. To view a copy of this licence, visit http://creativecommons.org/licenses/by/4.0/ The Creative Commons Public Domain Dedication waiver (http://creativecommons.org/publicdomain/zero/1.0/) applies to the data made available in this article, unless otherwise stated in a credit line to the data. 